\section{A MEMORABLE EXPERIENCE}

(Continued from Page 7)

as we were and, in a very short time, the news soon spread around town. They were indeed the rare and beautiful Whooping Cranes. By this time too, we had struck the acquaintance of Tim Sue Thom, the young son of the proprietor who was keenly interested in the outdoors. He had already edited some material for the High School paper and was well on the way to becoming an advocate for the protection of the Whooping Cranes. He asked if he might go with us. We were delighted for we had obtained our pictures, and there would still be a chance for him to see the birds. It gave us an opportunity to acquire the rest of the material we wanted that afternoon and, by the time the sun fell behind the hills in the west, our young friend had spent an afternoon with the Whooping Cranes and, while no further pictures were obtained, we felt that the day was as full as it could be. With a prayer on our lips, we left these beautiful creatures, hoping they would certainly make it for years to come.

We returned to Regina that same evening and, as a finale to the splendid co-operatior given by the people of Herbert, we promised to provide them with photographs of the occasion.

The next day I received a telephone call from Ralph Steuck, the Abernethy naturalist. His interest was so great that he decided to drive into Regina, following a show to the people of Cupar. I am happy that he and Fred Lahrman were able to drive to Herbert, early Saturday morning.

The day was spent in searching the area-but the birds had gone, due no doubt to the sudden change in the weather. By this time the public interest was so high in Herbert that Ralph decided, as a mark of appreciation for the interest and protection afforded the rare birds, to put on a show of nature movies.

The accompanying photographs are unusual ones. The larger one of the sequence, like the other two, was taken by Fred Lahrman. To me, it is the outstanding photograph of all. When you consider that it was taken in this vast area where it was only a chance in a million the birds would come close enough for such a shot, the extreme good fortune is apparent. I am happy that such a beautiful photograph was taken by one who so fully appreciates the real significance of the value of these rare creatures.

\section{WASCANA VALLEY}

\section{J. H. TAYLOR, Regina}

Far too few Regina persons realize that within a few miles of the city Wascana runs into a beautiful wooded valley. There in late summer trees and shrubs are in full leaf. Saskatoons, black currants, raspberries, gooseberries and pin cherries are either ripe or ripening.

Late summer flowers are in bloom. In July and August yellow is predominant color, cone flowers leading the parade. Wild currant, a late blooming shrub, is now in full flower. It has delightful pink blossom clusters and an exquisite perfume. Bergomot, which oldtimers dried for winter use, vies with its yellow neighbors in quantity and beauty. This is a miniature mauve chrysanthemum.

Young fluffy horned owls still wobbly in their flight wing from tree to tree. Shyer birds, brown thrashers, blackbilled cuckoos, arctic towhees and catbirds love this valley and make it their summer home. There are several beaver dams. Results of beaver logging operations may be observed. At a quiet hour in the evening one sometimes sees the busy fellows. Tracks of deer are plentiful though one seldom lights upon the beautiful creatures themselves.

From the banks flow some springs. One near the old crossing of buffalo hunting days seems to have mineral properties. Moss on its edges petrifies. Settlers of the neighborhood tell that petrified toads and frogs may be found by doing a little spade work. And for the geologist, scattered shale rocks on the upper hillside yield many fossils.

All this may be found on a late summer day almost within sight of Regina. 